Univerzitet u Beogradu
Poljoprivredni fakultet
Institut za poljoprivrednu tehniku
Naučni časopis
POLJOPRIVREDNA TEHNIKA
Godina XLV
$\begin{aligned} & \text { Broj 2, 2020. } \\ & \text { Strane: } 1-7\end{aligned}$
UDK: 338.43.1. $\begin{array}{r}\text { University of Belgrade } \\ \text { Faculty of Agriculture }\end{array}$

doi: $10.5937 /$ PoljTeh2002001V

\title{
IMPORTANCE OF IMPLEMENTATION OF DECISION MAKING FLOW BY INTERNAL AUDIT TO TOP MANAGEMENT OF AGRICULTURAL ENTERPRISE IN REPUBLIC OF SERBIA
}

\author{
Jelena Vitomir*1, Bogdan Laban², Dragana Popović3 \\ Vera Popović ${ }^{4}$, Dalibor Dončić ${ }^{5}$, Ranko Mijićc \\ ${ }^{1}$ Megatrend University, Faculty of Business Studies, 11070 N.Belgrade, R. of Serbia. \\ ${ }^{2}$ City administration of the City Subotica, 24000 Subotica, R. of Serbia. \\ ${ }^{3}$ Economic Faculty Subotica, 24000 Subotica, R. of Serbia. \\ ${ }^{4}$ Institute of field and vegetable crops, 21000 Novi Sad, R. of Serbia. \\ ${ }^{5}$ Independent University, 78000 Banja Luka, Bosnia i Hercegovina. \\ ${ }^{6}$ College of Economics and statistics, 79000 Prijedor, Bosna i Hercegovina.
}

\begin{abstract}
Internal audit should contribute to and ensure the safety of top management in all enterprises, and in particular in agricultural enterprises that rely on primary agriculture and processing of agricultural products. Internal audit, introduced into the regular control flows, enables the proper functioning of the existing management processes, especially the risk management of the top management's business and key decisions.

In addition, internal audit contributes to an increase in the control function and management of the company, that is, management processes that are close to the planned activities of top management, thus enabling the achievement of the basic goals of the company that is made by top management.
\end{abstract}

Key words: internal audits, process management, agriculture, risks.

*Corresponding Author. E-mail: jelena.vitomir1@gmail.com 


\section{INTRODUCTION}

The introduction of an internal audit enables the ever-increasing exercise of functions in any company [1] [2], [3], [4], [5], and in recent years, in the transition conditions, it has been of dominant importance in agricultural enterprises. Internal audit reports in the form of recommendations are submitted to top management with the aim of optimizing [6], [7], [8] the future management of the company.

Top management, if it wants to improve business results [9], [10], starting with the increase of production, increase of turnover, increase of profit, must pay attention to the recommendations of internal audit, because in the presentation of the results of internal audit, internal audit, opinion and the findings of the internal auditor and must provide guidance in their work that is consistent with the legislation [11].

Corporate governance in a large number of enterprises, and therefore in subagricultural enterprises, is based on the use of corporate finance management principles. A large number of heterogeneous legal entities respond differently to business decisions made. Management should monitor performance to ensure that activities are carried out optimally economically, efficiently and effectively.

Therefore, internal audit should result, first and foremost, in the field of quality control, both in production and in the sphere of sale of agricultural products and products.

Activities should be embedded in the management system, and any company with development aspirations should make adequate decisions that are timely, thought-out and development-oriented.

Management data are reviewed regularly to verify that they are appropriate for the agricultural undertaking. In addition, the performance of the business results must be valid in relation to the engagement inputs as regards the efficiency, cost-effectiveness and quality of service provided by the agricultural enterprise.

\section{MATERIAL AND METHODS}

The authors gave a possible sequence of events related to business decision-making in the agricultural enterprise, which implements the recommendations of the company internal audit. The authors provide a general model of the decision-making flow in Figure 1.

Modern business requires a new approach, which basically defines a large number of jobs that requires a new approach, which is reflected in the increasing degree of standardization of jobs, but also with the increasing operational risk and the speed of action towards management.

The general model of application is given by the authors as a general approach to the theoretical model of company behavior. The general model is presented in Table 1 by the authors.

The legal framework for the existence of public enterprises based on agriculture is made up of public enterprises, not so numerous, but it is necessary to emphasize that in the Republic of Serbia such enterprises are subject to special laws, such as: 
the Law on Budget System ("Official Gazette of RS", no. 54/2009, 73/2010, 101/2010, 101/2011, 93/2012, 62/2013, 63/2013-corr., 108/2013, 142/2014, 68/2015, 103/. 2015) [12].

In addition, I must respect: the existence of the Rulebook on Common Organization Criteria and Standards and Methodological Guidelines for the Implementation and Reporting of Internal Audit in the Public Sector ("RS Official Gazette", No. 99/11 and 106/13) [13].

\section{RESULTS AND DISCUSSION}

Presentation of important partial factors in the decision-making of top management that is aging and managing the operation of agricultural enterprises in the Republic of Serbia can be viewed in several ways. In this paper, the authors present a survey of 10 surveyed companies that are predominantly related to agricultural enterprises. The analysis covered the efficiency of the use of capital in the period 20142018, which concerned the analysis of profit margins, turnover of total assets, turnover of business assets, turnover of fixed assets, and turnover of current assets.

The views in Table 3 are given as an average of the sizes of 10 randomly analyzed companies, and the data obtained were obtained by primary processing of the final accounts data for the survey years shown.

The Internal Auditor performs his / her activities on the basis of procedures based on the previously adopted Charter on Internal Audit and the powers conferred by top management. In addition, an internal audit needs to define more precisely the area of business within an enterprise, such as accounting and company finance for a specified period.

The following is the designation of the person who will perform the internal audit, relative to the company's internal auditor. It then defines to whom the reports and recommendations are intended, for example: Internal Audit and Internal Audit Department, Chief Financial Officer, General Directorate, Board of Directors, etc.

In order to carry out audit procedures, the internal auditor proposes to agree on the dates for meetings of relevant persons.

The purpose of the working meetings is to inform the top management of the objectives, scope and procedures of the audit, as well as to provide answers to the issues that need to be highlighted in particular regarding the system audit.

The exact time and date of the meeting will subsequently be agreed upon in accordance with the obligations of the participants and will be notified to the internal auditor with the main activities. 


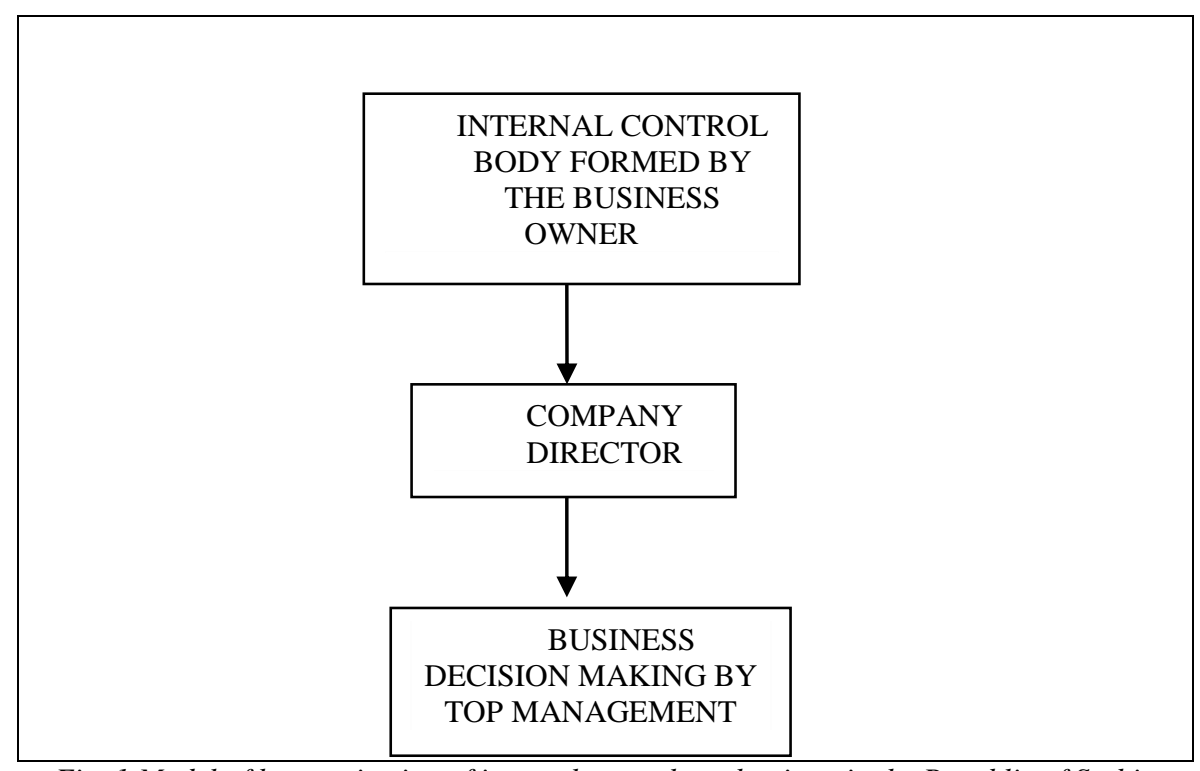

Fig. 1 Model of harmonization of internal control mechanisms in the Republic of Serbia

Table 1. Presentation of standardization form with description of possible control and possible level of risk for business of agricultural enterprise

\begin{tabular}{|l|l|l|l|}
\hline $\begin{array}{l}\text { Forms of } \\
\text { standardization }\end{array}$ & $\begin{array}{l}\text { Requirements regarding the performance } \\
\text { of control and audit }\end{array}$ & $\begin{array}{l}\text { Possible } \\
\text { risk level } \\
\text { per } \\
\text { company }\end{array}$ & $\begin{array}{l}\text { Undertaking } \\
\text { Management } \\
\text { activities }\end{array}$ \\
\hline standard & $\begin{array}{l}\text { Applying standard requires a } \\
\text { professional attitude, competence and } \\
\text { professional care, competence, } \\
\text { knowledge and other competencies to } \\
\text { perform internal audits. }\end{array}$ & Medium & $\begin{array}{l}\text { Directly after } \\
\text { the knowledge }\end{array}$ \\
\hline $\begin{array}{l}\text { Implementation } \\
\text { standards }\end{array}$ & $\begin{array}{l}\text { The auditor must obtain help, if there is } \\
\text { no knowledge, skills, or other } \\
\text { competencies needed to perform all tasks } \\
\text { related to the audit or his involvement. }\end{array}$ & High \\
\hline $\begin{array}{l}\text { Performance auditor must effectively manage } \\
\text { standards }\end{array}$ & $\begin{array}{l}\text { Mnternal audit activities. } \\
\text { Mast plan and prioritize internal audit, }\end{array}$ & High the assessed risk. & Immediately \\
\hline $\begin{array}{l}\text { Implementation } \\
\text { Standards- } \\
\text { advice }\end{array}$ & $\begin{array}{l}\text { The auditor should consider accepting } \\
\text { proposed involvement in the assessment } \\
\text { and should propose improving the } \\
\text { organization of the subject in which } \\
\text { audits. Data Solutions suggestions. }\end{array}$ & High \\
\hline
\end{tabular}


Table 2. Showing framework regulating the work of internal auditors in the R. of Serbia

\begin{tabular}{|c|c|c|c|}
\hline $\begin{array}{l}\text { Serial } \\
\text { number }\end{array}$ & $\begin{array}{l}\text { The existence } \\
\text { of a legal framework }\end{array}$ & Where were published & $\begin{array}{l}\text { Possible } \\
\text { risk level } \\
\text { per comp. }\end{array}$ \\
\hline 1. & Law on Budget System & $\begin{array}{l}\text { "Off. Gazette of } R S^{\prime}, \text { Nos. } \\
\text { 54/2009, 73/2010, 101/2010, } \\
\text { 101/2011, 93/2012, 62/2013, } \\
\text { 3/2013 corr., 108/2013, } \\
\text { 142/2014, 68/2015-other. } \\
\text { 103/2015 and law" }\end{array}$ & High \\
\hline 2. & $\begin{array}{l}\text { Regulations on common } \\
\text { criteria for organization and } \\
\text { standards and methodological } \\
\text { guidelines for the conduct and } \\
\text { reporting of internal audit in } \\
\text { the public sector }\end{array}$ & $\begin{array}{l}\text { "Off. Gazette of RS "no. 99/11 } \\
\text { and } 106 / 13\end{array}$ & High \\
\hline 3. & $\begin{array}{l}\text { Internal Audit Charter } \\
\text { companies }\end{array}$ & $\begin{array}{l}\text { NO. (...) From the date when it } \\
\text { was adopted (...) years }\end{array}$ & Medium \\
\hline 4. & $\begin{array}{l}\text { Authority given to the internal } \\
\text { auditor by Directors }\end{array}$ & $\begin{array}{l}\text { NO. (...) From the date when it } \\
\text { was adopted (...) years }\end{array}$ & Low \\
\hline
\end{tabular}

Table 3. Showing indicators of capital use for the period 2014-2018 in agricultural enterprises based on a random survey of 10 enterprises

\begin{tabular}{|l|c|c|c|c|c|}
\hline \multirow{2}{*}{\multicolumn{1}{|c|}{ Indicators }} & \multicolumn{5}{c|}{ Years } \\
\cline { 2 - 6 } & 2014 & 2015 & 2016 & 2017 & 2018 \\
\hline Profit margin & $1 \%$ & - & - & - & - \\
\hline Crafts of total property & 1,96 & 2,06 & 2,40 & 2,64 & 2,64 \\
\hline Craft business property & 1,96 & 2,06 & 2,40 & 2,64 & 2,64 \\
\hline Fixed property crafts & 4,73 & 5,40 & 6,67 & 6,44 & 6,65 \\
\hline Property & 3,24 & 3,57 & 3,72 & 3,77 & 4,25 \\
\hline
\end{tabular}

\section{CONCLUSIONS}

Contemporary management requires new ways of implementing the organization of work of top management. This requires the use of new working methods.

In this paper, the authors emphasize the importance of using control mechanisms, more specifically the use of internal audit in the functioning of an agricultural enterprise.

The results indicate the positive business trends of a company whose management has opted for the implementation of internal audit and the use of recommendations provided by internal auditors to achieve improvement in corporate governance. Thus, internal audit becomes a significant factor that can contribute to improving management in an agricultural enterprise.

The authors point out that with the introduction of internal audit and the obligation to provide rapid and qualitative reporting in the form of recommendations made by internal auditors to top management, the overall management of an agricultural enterprise can be improved in the short term. 


\title{
BIBLIOGRAPHY
}

[1] Williams, C. 2010. Principi menadžmenta. Data Status, Beograd.

[2] Northouse, P. 2008. Liderstvo. Beograd, Data Status.

[3] Popović S. 2014. Socio-ekonomski faktori ograničenja razvoja agrara. Monografija. FIMEK. Novi Sad.

[4] Cantino, V. 2009. Korporativno uptravjanje, merenje performansi i normativna usaglašenost sistema internih kontrola. Beograd, Data Status.

[5] Damodaran, A. 2007. Korporativne finansije: teorija i praksa. Podgorica, Modus.

[6] Popović, S., Ugrinović, M., Tomašević, S. 2015. Upravljanje menadžmenta poljoprivrednog preduzeća preko praćenja ukupnih troškova održavanja traktora. Poljop. tehnika. 2: 101-106.

[7] Popović, S., Ugrinović, M., Tomašević, S. 2015. Management of Agricultural Enterprises by Means of Fair Financial Reporting in Accordance with International Standards of the Finance and Accounting Reporting, CDQM. No3: 24-30.

[8] Popović, S., Mijić, R., Grublješić, Ž. 2014. Interna kontrola i interna revizija u funkciji menadžmenta. Škola Biznisa. 1., 95-107.

[9] Popović, S., Tošković, J., Majstorović, A., Brkanlić, S., Katić, A. 2015. The importance of continuous audit of financial statements of the company of countries joining the EU, Annals of the „Constantin Brâncuşi” University of Târgu Jiu, Economy Series, Special Issue, pp.241-246.

[10] Wyatt A, 2004. Accounting professionalism: they just don't get it !. Accounting Horizons. 18, pp. 45-53.

[11] Popović S. 2015. Implementacija heterogenih rizika u radu interne revizije, Revizor 69/2015, Institut za ekonomiku i finansije. Beograd.

[12] The Law The Budget System of the Republic of Serbia. Available:

http://paragraf.rs/propisi/zakon_o_budzetskom_sistemu.html, accessed: 02.12.2019.

[13] Regulations on common criteria for organization and standards and methodological guidelines for the conduct and reporting of internal audit in the public sector, available: http://www.budzet.vojvodina.gov.rs/wp-content/uploads/2016/01/13.-novembar-2015godine-sistematizacija.pdf. Accessed: 02.12.2019.

\section{ZNAČAJ IMEPLEMENTACIJE TOKA ODLUČIVANJA OD STRANE INTERNE REVIZIJE PREMA TOP MENADŽMENTU POLJOPRIVREDNOG PREDUZEĆA U REPUBLICI SRBIJI}

\author{
Jelena Vitomir ${ }^{1}$, Bogdan Laban ${ }^{2}$, Dragana Popović ${ }^{3}$, \\ Vera Popović ${ }^{4}$, Dalibor Dončić ${ }^{5}$, Ranko Mijićc \\ ${ }^{1}$ Megatrend Univerzitet, Fakultet za poslovne studije, Bulevar Marsala Tolbuhina 8, \\ 11070 Novi Beograd, R.Srbija. \\ ${ }^{2}$ Gradska upava Grada Subotice, Trg Slobode 1, 24000 Subotica, R.Srbija. \\ ${ }^{3}$ Ekonomski Fakultet Subotica, Segedinski put 9-11, 24000 Subotica, R. Srbija. \\ ${ }^{4}$ Institut za ratarstvo i povrtarstvo, Maksim Gorkog 30, 21000 Novi Sad, R.Srbija. \\ ${ }^{5}$ Ekonomski fakultet, Nezavisni Univerzitet Banja Luka, Majke Jugovića 4, 78000 \\ Banja Luka, Bosna i Hercegovina. \\ ${ }^{6}$ Visoka škola za ekonomiju i informatiku, Mitropolita Petra Zimonjića bb, \\ 79000 Prijedor, Bosna i Hercegovina.
}


Sažetak: Interna revizija treba da doprinese i obezbedi sigurnost u radu top menadžmenta u svim preduzećima, posebno u poljoprivrednim preduzećima koja se oslanjaju na primarnu poljoprivredu i preradu poljoprivrednih proizvoda. Interna revizija, uvedena $\mathrm{u}$ redovne tokove kontrole, omogućava pravilno funkcionisanje postojećih procesa upravljanja, posebno upravljanja rizikom poslovanja top menadžmenta u momentima donošenja ključnih poslovnih odluka.

Pored toga, interna revizija doprinosi povećanju kontrolne funkcije u upravljanju preduzećem, odnosno upravljačkim procesima koji su bliski planiranim aktivnostima top menadžmenta, omogućavajući postizanje zadovoljavanja osnovnih ciljeva kompanije koji su postavljeni pred top management.

Ključne reči: interna revizija, upravljanje procesima, poljoprivreda, rizici.

Prijavljen:

Submitted:

03.12.2019.

Ispravljen:

Revised:

01.05.2020.

Prihvaćen:

Accepted:

05.05.2020. 